\title{
Implementation Impact of an Integrated Scientific Moral-values Instructional Model on the Improvement of the Elementary School Students' Moral-Character
}

\author{
Sri Saparahayuningsih \\ Faculty of Teacher Training and Education Bengkulu \\ University Indonesia \\ mbmbadeni@gmail.com
}

\author{
Badeni \\ Faculty of Teacher Training and Education Bengkulu \\ University Indonesia \\ mbmbadeni@gmail.com
}

\begin{abstract}
The purpose of this research is to know the impact of the implementation of an integrated scientific moral-values instructional model on the development of the elementary school students' moral character. The research was conducted in the form of test-retest experiment. The results of this research showed that the implementation of the integrated scientific moral-values instructional model in the instructional process of social studies is able to increase $67 \%$ of the improvement the moral- characters compared to the implementation scientific approach contained in the content of social studies to the student intact. The integrated scientific moral-values instructional model is very effective to develop students' moral-characters.
\end{abstract}

Keywords-effectivity; implementation;moral-character; and integrated scientific moral-values instructional model.

\section{INTRODUCTION}

One of the various aspects of the review that lies behind the development of the curriculum in 2013 is alarming sociocultural change. The impact of this change, especially at this time, there was revolutionary in all aspects of life in the political, economic, social, cultural, behavioral and other dimensions of life as in [1]. Examples of socio-cultural changes are marked with Indonesian culture that was once known courteous, polite, gentle, caring for others, high society, and high cooperate shifted into a nation that less social sensitivity, and selfish. There was also rampant corruption, and student brawls occur everywhere. This change also occurs in both the developed and developing countries. Reportedly, the learners in the United Kingdom for instance, that the impact of science and technology as an increase in harmful behavior, anti-social behavior, indiscipline, under-achievement as in [2], drunkenness, unsafe sex as in [3], and the increase in juvenile delinquency in the community. Even the most remote villages and big cities in Indonesia, the symptoms have come to a very disturbing extent, such a fight mass, parents kill her own child, husband kills his wife and vice versa, teen fights, fighting between learners and between schools, rampant corruption, social sensitivity barren and various other cases of moral decadence. These symptoms due to the declining value of social and community life as in [4].

In connection with this, today's society felt that the implementation of education about values, attitudes, and character of the institutions of formal education is very important, and urged increased intensity and quality. Formal education institutions, especially elementary school (ES) as an official container coaching children and young people, is expected to increase its role in shaping the character of learners through increasing the intensity and quality of education on values, attitudes, and character. The government welcomed insistence by pouring the main target to be achieved in the curriculum in 2013, namely the formation of attitudes and character of the young generation as in [5]. The problem though in the 2013 curriculum has set the values of attitude and character to become the main target of achieving the goals of education, have chosen learning model really be learning model, when it is applied, capable of achieving these objectives?

Educational experts generally agree on the importance of efforts to increase the intensity and quality of the attitude and character education in formal education. However, there are differences of opinion among them about the approach and mode of education. Associated with the approach, some experts suggest the use of moral education approaches developed in western countries, such as the approach of cognitive moral development, value analysis approach, and values clarification approach. Others suggest the use of traditional approaches, namely through the planting of certain social values in selflearners. Attitude and character education in the school curriculum in Indonesia, the curriculum in 2013, developed a model of learning with the scientific method approach. Is the scientific method approach is able to achieve the goal of education values, attitudes, and character expected? Based on the study of various theories doubt that implementation the scientific method is able to achieve the goal of education values, attitudes, and character expected. Step-by-step approach to learning that is applied to the scientific method, only able to familiarize learners scientific attitude in learning, namely the process of receiving, searching, collecting, formulate, and report information, has not been able to get used to the for- 
mation of moral-character as expected by the curriculum 2013, namely "respect and appreciate the teachings of their religion (first core competence)" and the attitude expected by curriculum 2013, namely "respect and appreciate the honest behavior, discipline, responsibility, caring (tolerance, mutual aid), mannered, confident, in interacting effectively with the social and natural environment "(second core competence) as in [5]. Related the cases, in 2015 we did a research. Based on the research had been found an instructional approach viewed as an approach which is of the most appropriate to develop students' moral-character in elementary schools (ES).The approach is called an integrated scientific instructional approach.The question is "what does look like of the implementation impact of the approach on the improvement of ES students' moral character? Looking at the above-mentioned problems the researchers tried to research the implementation impact on the development of ES students' moral character.

It seems to be better to achieve the objectives of the research by studying the theories of values and characters as follows.

Conceptually, attitude and character education is the direct and indirect intervention by various institutions such as the family, religious institutions, and schools that affect developments in values, attitudes and character of a person, including developments in behavior, the ability to think about whether the issues right or wrong, the actual opinion right or wrong that someone hold as in [6]. He also noted that the formal purpose of education values, attitudes and character should take into account (1) the actual act of someone that contain the situation it was right or wrong. (2) The person's ability to think critically to moral problems, and (3) the opinions of actual moral maintained by the individual [7]. To achieve the goal of values, attitudes, and character, experts have proposed various theories about moral education. There are five typologies that inculcation of values education, moral development, analysis, value clarification, and action learning approaches as in [8].

Inculcation Approach is an approach that gives emphasis on the cultivation of social values in self-learners. The Approach to education about values, attitudes and character aims: (1) instill certain values in self-learners; (2) changing social values unwanted learners toward the desired value. A lot of support in addition to criticism of this approach. Reference [8] says most educators ... see values as socially or culturally accepted standards or rules of behavior. Children actively incorporate these values into him naturally. While critics of this approach say (1) "believe that values originate in an omnipotent Creator. (2) This approach is seen indoctrination, not in accordance with the development of democratic life ${ }^{7}$. This approach neglecting the children's right to freely choose their own value. Human life is different because of differences in time and place. We cannot predict the corresponding value for generations to come. According to the above opinion, every generation has the right to determine their own value. Therefore, the need to be taught to students instead of value, but rather the process, so they can find their own values, in accordance with the place and era.

A moral development approach is an approach to moral development that gives emphasis on the cognitive aspects and development. This approach encourages students to think actively about moral issues and make moral decisions. The educators who adopt a development perspective of moral values and character attitudes believe that moral thinking individual develops in stages through a particular sequence in making a moral judgment of a lower level toward a higher level as in [9].

Dewey first proposed historically cognitive development approach. He divided the children's moral development into three stages (levels) as follows: (1) Stage "pre-moral" or "preconventional". In this stage a person's behavior is driven by an urge that is physical or social; (2) Phase "conventional". In this stage, a person begins to accept with little critical value, based on criteria group. (3) Phase "autonomous". In this, stage a person to act or behave in accordance with the mind and judgment to himself, not fully accept his group criteria. While Piaget made a conclusion that, the development of cognitive abilities in children affects their moral considerations.

Value educational purposes according to the moral development of this approach are (1) to help students develop patterns are more complex moral thinking that is based on a series of higher moral values, (2) encourage learners to discuss the reasons why the choices and position their moral values, not only to share with others but also to obtain a change levels of moral values reasons learners.

This approach uses learning methods to provide moral dilemmas discussed in small groups to obtain answers argumentative and relatively structured and do not necessarily have to come to a right or wrong answer. Through the moral argument is what allows children internalize the values of information received. However, something to keep in mind that for lowgrade children of primary school age are still relatively heavy to be invited to think critically and argumentative and moral will is formed through habituation. Routines shape habits, which in turn establish attitudes as in [3]

Analysis approach places emphasis on the development of the learner's ability to think logically and scientific investigations, by analyzing the problems associated with social values. If the comparison between the value analyses approaches to cognitive development approach, one important difference between the two that the analysis approach, more emphasis on the discussion of issues that includes social values. The cognitive developmental approach places emphasis on the moral dilemma they are individual. This means that the cognitive development approach and analysis approach have similar patterns of thought, both are just different targets. Therefore, both have advantages and disadvantages of similar applications. Advantages, this approach is able to develop critical thinking, while weakness, this approach is relatively difficult to be applied to the age of the children of low grade.

There are two main objectives of moral education according to this approach, namely (1) helps learners to use a scientific and logical thinking skills in analyzing social issues, which relate to certain moral values; (2) helps learners to use rational thinking and analytical processes, the connection between and formulate the concept of their values. 
Values clarification approach is an approach to learning which gives emphasis on the business of helping learners to assess their own feelings and actions, to increase their awareness of their own values. The purpose of education according to the value of this approach, there are three, that is to help learners to be able to (1), be aware of and identify their own values and the values of others; (2) communicate openly and honestly with others, dealing with its own values; (3) using jointly the ability to think rationally and emotional awareness, to understand the feelings, values, and behavior of their own [7]. In accordance with its objectives, this approach will allow the child to analyze the truth-values he had, to be honest with yourself and others and able to think rationally and improving emotional awareness.

This approach contains two main objectives: (1) provide an opportunity for learners to perform moral actions, either individually or jointly, based on their own values; (2) encourage students to see themselves as individual beings and social beings in association with others, who do not have complete freedom, but as citizens of a society as in [7]. In addition to applying learning methods applied in the value analysis approach and values clarification, this approach also implements specific projects at school or in the community, and practice skills in the organization or in connection among as in [8].

This approach will be able to increase the awareness, willingness to participate in the social life of the community, but not all the values of social studies learning materials can be applied directly. As we know, that each of these approaches has advantages and disadvantages of each. By thus be necessary to develop an approach that contains all the goodness or the integration of the principles of the six theories. Principles of instructional or educational value, attitude and character as follows: (a) does not ignore the rights of the child learners to choose their own value (not indoctrinated); (b) emphasize the process can find the values of their own, according to the place and time; (c) encourage learners to think active, rational, analytical and argumentative in analyzing and making moral decisions; and (d) through moral argumentative, awareness of logical/rational, scientific and moral habituation acts (individual or group) students will internalize the values received.

Based on these principles can be rationally accepted that the value of learning approach, attitude, and character of the applied science by integrating a whole repertoire of these theories (character, attitude, and values with an integrated learning approach scientific values) would be the most appropriate approach in the implementation of education values, attitudes and characters in Indonesia. This approach will enable the fulfillment of the basic capital of the individual in the learning process both in attitude, knowledge, and skills in addition to meet the growing efforts of the noble values of Indonesian culture and philosophy of Pancasila.

Based on the principles of values, attitudes and character learning, the team of researchers had developed learning approach of values, attitudes, and character-based social studies curriculum material content 2013 for ES students. The learning approach was named as an integrated scientific moral-values instructional approach. Then, we want to know the impact of the approach implementation on the development of the elementary school students' moral character.

\section{METHODS}

This research was designed to know the impact of the implementation of an integrated moral-values instructional approach on the improvement of the moral character of ES students.

Related to the purpose, the research was conducted by testing the effectiveness of the approach implemented in the improvement of the moral character of Elementary school (ES) students in the form of test-retest experimental research. The elements of students attitudes and character observed were "respect and appreciate the teachings of their religion, respect and appreciate the honest behavior, discipline, responsibility, caring (tolerance, mutual aid), mannered, confident, in interacting effectively with the social and natural environment. The population of this research were the fifth grades of public ES in Bengkulu with accreditation of B. For the sake of balance, the samples of this research were taken in three district areas, they were $25 \%$ of ES from one municipality and two counties. After being selected at random, this samples of research consisted of 30 classes from 20 ES. The subjects of this research were educational administrators, social studies teachers, and students. Data were collected through focus group discussions, observation, interviews and one group pretest-posttest experimental design. Specifically, data related to students' moral-character were collected through evaluation of peer student observation.Collected data were analyzed with t-test technique.

\section{RESULTS AND DISCUSSION}

\section{A. Result}

Based on data from the results of trial observation of integrated scientific instructional approach were analyzed by the methods of data analysis One-Sample Statistics SPSS 16. The results of the analysis are as follows.

Based on the analysis of the data SPSS 16 such observations we found that the value of $37.417 \mathrm{t}$ and significance of 0:00 was under the $95 \%$ level of significance. This means there are significant differences between the moral character of students that had been learned by social studies teachers using a scientific approach with students that had been learned by social studies teachers using an integrated scientific instructional approach. This difference we can see a real if we consider the average value and character between the average value of students' attitude and character that had been learned by social studies teachers using a scientific approach and the average value of students'attitude and character that had been learned by social studies teachers using integrated scientific instructional models. The average value of the results of trials using a scientific approach found an average value of the moral character of students at 2:095, while the average value and character of students that had been learned by social studies teachers using "integrated scientific moral-values instructional model" found the average value of the students'attitude and character of 3.142. Data from the analysis showed that there are differences an average score of attitude and character between the use of scientific approach and the 
use of integrated scientific moral-values instructional models for $2: 095<3: 142$ (1.047). In other words, there are average differences between the average score of moral-character between the use of scientific approach and the use of integrated scientific moral-values instructional model "1.047 or $=67 \%$ ). This means that the application of the learning approach "integrated scientific moral-values instructional model " is able to increase changes in attitudes and character of learners by $67 \%$, which means that the learning approach "integrated instructional scientific model" is very effective to enhance the character of changes in values and attitudes of learners.

\section{B. Discussion}

The results of research showed that learners being learned by using integrated scientific moral-values instructional model are much faster growing spiritual attitudes, social attitudes (honest, discipline, responsibility, caring, tolerance, cooperation), polite, confident, in interacting effectively with the social and natural environment in comparison with the application of scientific approach teacher. This happens because the learning values and attitudes or character-based integrative scientific model, learners are deliberately invited to explore, understand, make sense of the values contained in the subject matter being studied. Digging experience, understand and make sense of values that exist in the content of learning material makes learners become totally accept or logical reason why such values that need to be viewed, copied and applied in society. This awareness makes students feel happy and want to maintain those values. In other words, this awareness makes the values embedded into itself or into the attitude and character of students. This is in line with the opinion of the Dharma Kusuma, Cepi Triatna and Johar Permana, that the logic and rationality that is the important measure to produces a rich person's decisions as in [9]. Someone will do and do it steady when everything is done rationally acceptable. Examples of behavior can be easily accepted if anything; it has a sense of acceptance. Something that is accepted by the mind will develop in a person into something that is felt to be liked or disliked by her feelings. Something like will be a value that is a tendency attitude that encourages you to do and will even try to defend and fight for it. Reference [10] also said that the attitude contains cognition, feelings, and behavior tendency to act on an object. Cognitive influence positive or negative feelings and feelings affect the tendency to act ${ }^{21}$. Affective-cognitive consistency theory suggests that the affective component of the attitude of the system may be changed by first changing the cognitive component through providing new information as in [11].

Individual attitudes toward an object depend on the information obtained from an object is perceived as positive or negative. Changes in individual cognition of an object will tend to result in changes in feelings and tendencies toward an object. Thus, the rational acceptability of information is considered as a positive or negative will affect the propensity to act on that object. In other words, the acceptance of information from the subject matter in the form of the values that have been analyzed rationally why it needs to be done, what are the benefits, how to do it by the individual concerned will strengthen the tendency to act or attitude towards these values. Decisions of the object to do something or not, maintained or not is determined by the rationality of the acceptability of an object. Decisions on the outcomes of learning something of value to be done or not, maintained or not is determined by the rationality of acceptance into a value that has been studied as something that is rational or not. If the value that has been received because of thinking rationally, perceived goodness and usefulness in life, done repeatedly over time it will become an ingrained habit. An ingrained habit has become a cultural meaning in life or has become a character in his life. Thus the development of character through the learning process will be formed, when the learning process is done through an activity that makes learners become aware of what the nature of the study, what the values contained therein, where the values need to be emulated, why is the value that needs to be replicated and maintained, practiced in daily life repeatedly.

Routines shape habits, which in turn establish attitudes as in [12]. Something good is seen to be done, and done repeatedly will become entrenched customs and or internalized in him, so that they feel reluctant and felt there was something missing when abandon, and feel the need to preserve and maintain the value as in [10]. That is something that is obtained from the study of an individual will be a character in itself, if practiced in daily life continuously

The application of the integrated scientific learning approach is very effective to make elementary students understanding, preserving, maintaining and handling the learned values, habituating the value in daily life activity, and becoming internalized in them.

\section{CONCLUSION}

The results of this study showed that (1) scientific learning approach is only able to develop scientific attitudes of students, while sorts of other attitudes very less embedded into the self. (2) The application of the integrated scientific learning approach is very effective to instill the values of attitudes and characters contained in the content of social studies to the student intact.

\section{ACKNOWLEDGMENTS}

Firstly, we would like to first acknowledge the Directorate of Higher education Ministry of Research and Technology Republic of Indonesia that provided a fund for this research project. Secondly, we would like to thank for all of the head of the research and social service Board Bengkulu University who coordinated and facilitated administration of this research project. Lastly, we would like to thank all the heads of public Elementary School Bengkulu Municipality and, all the heads of Elementary School Bengkulu Centre County, and all the heads of Elementary School Seluma County, teachers, support staff, and students who helped us develop and complete this project through their participation and cooperation.

\section{REFERENCES}

[1] Abdul Aziz Wahab dan Sapriya (2011). Teori dan Landasan Pendidikan Kewarganegaraan. Bandung: Alfabeta, 2011

[2] Arthur, J., 2005. The Re-emergence of Character Education in British Education Policy. British Jurnal of Educational Studies, 53, 239-254. 
[3] White, Robert, Michael (2008). Building Schools of Character: The Development, Implementation, and Evaluation of a School-Based Character Education Programme Designed to Promote Cooperative Learning and Reduce Anti-Social Behaviour, Durham theses, Durham University. Available at Durham E-Theses Online: http://etheses.dur.ac. uk/189/

[4] Koran Sindo, 28 Januari 2014).

[5] Menteri Pendidikan dan Kebudayaan(2014). Buku Guru Ilmu Pengetahuan Sosial Kelas VIIIl. Jakarta: Kementerian Pendidikan dan Kebudayaan.

[6] Miller, Mary (2012). Teaching and Learning in Affective DomainEmerging Perspective http://projects. coe.edu/epltt/ index.php?title $=$ Teaching

[7] Lipe, David(2010). A Critical Analysis of Values Clarification. Montgomery (USA): Apologetic Press, Inc.
[8] Huitt, W. Values (2004). Educational Psychology Interactive. Valdosta, GA: Valdosta State University. Retrieved [date], from http://www. Edpsycinter-active.org/topics/ affect/ values.html

[9] Dolph, Katie and Lycan, Angela (2008). Moral Reasoning: A necessary Standard of Learning in Todays Classroom. Journal of CrossDisciplinary Perspectives in Education, Vol. 1, No 1,May.

[10] Sarlito Wirawan Sartono (2010). Pengantar Psikologi Umum, Jakarta: Rajawali Pers.

[11] Mohammad Arwani, 2008. Memaknai Tradisi Berkat Muludan di Kranjin Purworejo dalam Irwan Abdullah, Ibnu Mujib, M. Iqbal Ahnaf (Ed,). Agama dan Kearifan Lokal dalam Tantangan Global. Yogyakarta: Sekolahpascasarjana UGM, pp.187-2011.

[12] Sugiyono (2008). Metode Penelitian Pendidikan: Pendekatan Kuantitatif, Kualitatif, dan R \& D. Bandung: Alfabeta. 